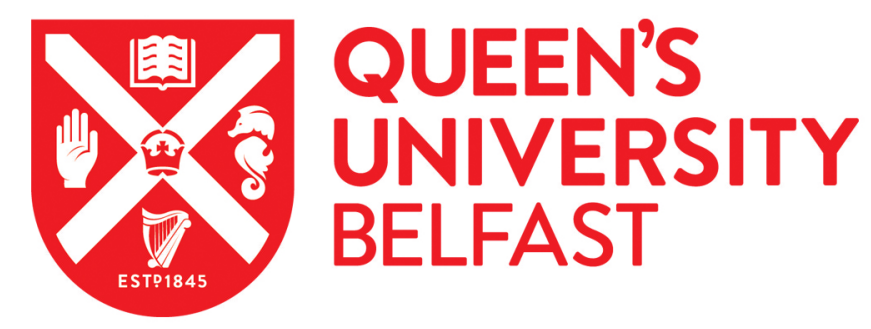

\title{
Cultural threat and anti-immigrant prejudice: The case of Protestants in Northern Ireland
}

Pehrson, S., Gheorghiu, M., \& Ireland, T. (2012). Cultural threat and anti-immigrant prejudice: The case of Protestants in Northern Ireland. Journal of Community and Applied Social Psychology, 22(2), 111-124. https://doi.org/10.1002/casp.1105

Published in:

Journal of Community and Applied Social Psychology

Document Version:

Early version, also known as pre-print

Queen's University Belfast - Research Portal:

Link to publication record in Queen's University Belfast Research Portal

\section{General rights}

Copyright for the publications made accessible via the Queen's University Belfast Research Portal is retained by the author(s) and / or other copyright owners and it is a condition of accessing these publications that users recognise and abide by the legal requirements associated with these rights.

Take down policy

The Research Portal is Queen's institutional repository that provides access to Queen's research output. Every effort has been made to ensure that content in the Research Portal does not infringe any person's rights, or applicable UK laws. If you discover content in the Research Portal that you believe breaches copyright or violates any law, please contact openaccess@qub.ac.uk. 
CULTURAL THREAT AND ANTI-IMMIGRANT PREJUDICE: THE CASE OF PROTESTANTS IN NORTHERN IRELAND

Samuel Pehrson

Mirona A. Gheorghiu

Tomas Ireland

(Queen's University Belfast)

This is a pre-peer reviewed version of the following article:

Pehrson, S., Gheorghiu, M. \& Ireland, T. (2011). Cultural threat and anti-immigrant prejudice: The case of Protestants in Northern Ireland. Journal of Community and Applied Social Psychology, 22, 111-124.

Published in final form at:

http://onlinelibrary.wiley.com/doi/10.1002/casp.1105/abstract 
Abstract:

Using data from the 2002 and 2009 Northern Ireland Life and Times (NILT) surveys, we examine attitudes towards immigrant and ethnic minority groups in Northern Ireland. We suggest that Protestant and unionist communities experience a higher level of cultural threat than Catholic and nationalist communities on account of the 'parity of esteem' principle that has informed changes in the province since the Belfast Agreement of 1998. Our analyses confirm that Protestants and unionists do indeed report more negative attitudes towards a range of immigrant and ethnic target groups compared to Catholic, nationalist or respondents who do not identify with either religious or political category. The analyses further suggest that their higher level of perceived cultural threat partially accounts for this difference. We argue that cultural threat can be interpreted as a response to challenged dominant status rather than as an inevitable response to minorities' cultural difference per se.

Key words:

cultural threat; ethnic prejudice; immigration; nationalism; Northern Ireland; Ulster unionism 


\section{Cultural threat and anti-immigrant prejudice: The case of Protestants in Northern Ireland}

The twelve years since the signing of the Belfast Agreement in 1998 have seen Northern Ireland emerge from a period of conflict known as 'the Troubles', which had claimed 3,000 lives over 30 years. The process of transition to a stable and peaceful society has inevitably attracted the attention of social scientists and produced volumes of scholarship on the matter. Within social psychology, the research agenda has concentrated, understandably enough, on relations between the protestant community on the one hand, and the catholic community on the other. Social psychologists studying Northern Ireland have typically asked how much, in this postconflict period, these groups trust, like and seek contact with each other, and how the psychological precursors of 'reconciliation' can be brought about (e.g. Cassidy \& Trew, 2004; Hewstone, Cairns, Voci, Hamberger, \& Niens, 2006; Muldoon, Trew, Todd, Rougier, \& McLaughlin, 2007; Livingstone \& Haslam, 2008; Tam, Hewstone, Kenworthy, \& Cairns, 2009).

Yet, the years since the Belfast Agreement have seen other changes that are relevant to intergroup relations in the province. Significantly, immigration has added to the previously rather small ethnic minority populations. For example, since the enlargements to the European Union in 2004 and 2007, a small but significant East European population has also become established. Indeed, the arrival of migrants could be read positively as a sign of the 'normality' that politicians and commentators on Northern Ireland crave. Unfortunately, though, the past decade has seen a rise in hostility towards immigrants to the point that Belfast has been dubbed the "hate crime capital of Europe" in the national media on account of the frequency of physical 
attacks against these new minorities, as well as homophobic and sectarian incidents and attacks on disabled people (Northern Ireland Affairs Committee, 2005). Media attention peaked in June 2009, when 100 Romanians were forced out of their homes following a series of such attacks, eventually having to leave the country after being told that the police could not guarantee them protection (although they reportedly returned to Northern Ireland some months later). The fact that these particular attacks took place in a protestant area of the city, fuelled a perception that such hostility was particularly prevalent among the Protestant population (Jarman, 2008).

Hostile reactions to immigration are not particular to Northern Ireland, and in a sense these events can be seen as reflecting a broader pattern observable throughout Europe. However, it may be instructive to consider how racism is connected to the particular social conditions that shape life there. Belfast, for example, is not just any city, but one characterised by exclusive sectarian and ideological residential spaces, whose boundaries are enforced through violence (Shirlow \& Murtagh, 2007). Furthermore, as we shall explain, the Belfast Agreement itself brought about a number of legal and institutional changes that aimed to undo the institutional dominance of Ulster unionism. These changes, have provoked a widespread sense of resentment and cultural threat that has been termed 'protestant alienation' (Southern, 2007). Our aim in the current contribution is to probe more systematically the view that Protestants in Northern Ireland have reacted to immigration with more hostility than Catholics have, and to examine why this might be the case.

\section{Cultural threat and attitudes about immigration}

One of the recurring themes in the research literature on anti-minority and anti-immigrant attitudes has been that of cultural threat, understood as the sense that 
an outgroup is in danger of somehow polluting or obstructing the expression of defining ingroup values, identity or traditions (Sides \& Citrin, 2007). A number of studies conceptualising cultural threat in this way appear to confirm its role as a robust predictor of anti-immigrant and anti-minority positions. In the UK, for example, it predicts desire to reduce immigration (McLaren \& Johnson, 2007). Analysis of multi-national survey data indicates that a perceived cultural threat is predictive of hostile orientations towards immigrants, and of low social and political tolerance of ethnic minorities across multiple European populations (McLaren, 2003; Weldon, 2006).

Furthermore, by using experimental designs within representative surveys in the Netherlands, Sniderman and Hagendoorn (Sniderman, Hagendoorn, \& Prior, 2004) demonstrate the mobilizing potential of cultural threat. Leading people to believe that a group of immigrants will not 'fit in smoothly with Dutch culture' did not merely strengthen the attitudes of people who already oppose immigration, but dramatically increased the proportion of respondents reporting such opposition: from a minority of 35 percent to a substantial majority of 85 percent. Thus, notwithstanding the particularity of anti-immigrant sentiment from place to place, accumulating evidence appears to support a key and reliable role for perceived cultural threat across contexts.

At the same time, however, there is a danger of tautology in demonstrating the link between cultural threat and negative attitudes (2007; see also Sniderman et al., 2004). Cultural threat is typically measured using questionnaire items that specify minority outgroups as the source of the threat: for example in the 1997 Eurobarometer survey analysed by Weldon (2006), participants are asked to indicate their agreement with the statement, "the cultural and religious practices of people from these minority 
groups threaten our way of life". Such measures, it is suggested, are likely to elicit agreement from anybody who dislikes the groups in question, regardless of the actual source of the prejudice. Sniderman et al. (2004, see also Sniderman \& Hagendoorn, 2007) demonstrate the high level of common variance between different forms of threat (for example, cultural and economic, individual and collective) when they are measured using items formulated in this way. They argue that this demonstrates the extent to which traditional threat measures merely tap a generalized antipathy towards the outgroup and that evidence demonstrating statistical relationships between such variables and prejudice has limited value. More useful, perhaps, would be a focus on the states of collective vulnerability that lead the cultural difference of certain groups to be interpreted as alien and threatening.

For example, in the British context, Gilroy (2004) approaches these phenomena through his notion of 'postimperial melancholia'. He attributes the persistence and character of British unease about immigration and multiculturalism to a collective failure to relate sensibly to the country's imperial past and its loss of prestige following the Second World War. Thus, anxiety about cultural threat is part of a wider narrative of deterioration, wherein the golden age of British strength, cohesion and moral certainty is symbolised most lucidly by Winston Churchill and the Battle of Britain (with the role of commonwealth forces in that moment of history largely erased from collective memory). Not only is immigration blamed for the loss of the sense of certainty and national community since that golden age, but also cultural difference itself comes to signify decline and provoke resentment.

These themes are strongly evident in Clark and Garner's (2010) analysis of white English people's talk about community. Interviewees largely shared a representation of Englishness as inseparable from white ethnicity and as being 
increasingly marginalized in multicultural Britain: every other category of people, they believe, is illegitimately advantaged over white English people. Such sentiments can be interpreted as a backlash against the reduced dominance of white ethnicity compared to earlier times, and Clark and Garner note the frequency of tropes such as 'the pendulum having gone too far' in delivering minority rights. A particularly telling manifestation of this backlash can be seen in the mythical bans on Christmas, supposedly pursued by local councils in fear of offending religious minorities, and which are cited by some of their interviewees. Such bans, though non-existent (at least since the Puritan ban of the $17^{\text {th }}$ century), appear to be widely believed in, perhaps because they articulate popular anxieties over the fact that white Christian people can no longer claim exclusive ownership of the British state. The possibility that cultural threat may be a manifestation of resentment over the undermining of an ethnic group's privileged status will be our focus as we turn to the case of Northern Ireland.

\section{Cultural threat in Northern Ireland}

In Northern Ireland, cultural threat has been identified as a mediator of the effect of religious salience on Protestants' attitudes towards Polish immigrants: when the predominance of the Catholic religion among Polish people is emphasised, they are seen as more threatening by Protestants, and hence as less welcome (van Rijswijk, Hopkins \& Johnston, 2009). This provides an important demonstration of how social categorization processes can alter the extent to which a particular immigrant group is interpreted as culturally threatening. However, we suggest that religious or cultural distinctions per se do not inevitably give rise to cultural threat. Northern Irish Protestants presently perceive a more acute general sense of cultural threat to their 
group than do Catholics, which, as we shall explain, is rooted in current political circumstances. We argue that this affects their attitudes towards a range of immigrant groups that differ just as much from Catholics in the province than they do from Protestants.

Between the partition of Ireland in 1921 and the onset of 'the Troubles' in the late 1960s, the Northern Irish state was dominated both politically and economically by the Protestant majority, who were overwhelmingly in favour of continued British sovereignty over the province. In political life, this entailed the hegemonic and continuous control of government enjoyed by the Ulster Unionist party, and the marginalisation of the (mainly Catholic) Irish nationalists from politics through gerrymandering and laws restricting expressions of Irish nationalism. In economic life, it meant discrimination against Catholics in the workforce. Military and police personnel were drawn almost exclusively from the Protestant population.

Given that the institutionally privileged position of the Protestant unionist population was a central grievance underlying support for the armed Irish Republican campaign against British rule, the peace process in Northern Ireland has inevitably entailed various measures to bring about 'parity of esteem' between the two main communities (Hennessey \& Wilson, 1997; Shirlow \& Murtagh, 2006). Significant commitments in this regard include new anti-discrimination employment legislation, and a re-branding and re-organisation of the police service from a basically unionist Royal Ulster Constabulary (RUC) to a more neutral Police Service or Northern Ireland (PSNI), with positive discrimination to bring about a police force drawn equally from both Protestant and Catholic population. Not surprisingly, this reconfiguring of the officially sanctioned role of the state, from safeguarding the union to delivering equal legitimacy and status to Irishness and Britishness, has been much 
less popular with Protestants than it has with Catholics (Shirlow \& Murtagh, 2006;

Mac Ginty \& du Toit, 2007; McAuley \& Tonge, 2007; Southern, 2007).

Shirlow and Murtagh (2006) have argued that the new institutional arrangements in Northern Ireland impose group competition between Protestant and Catholic communities, which are also reified as autonomous 'cultural traditions'. Politics is seen to be about balancing competing claims to group rights stemming from their respective needs for prestige, legitimacy and validation of these traditions. This often manifests in disputes that carry a cultural gloss, such as the status of the Irish or Ulster Scots languages, or restrictions on what institutions such as the Orange Order see as traditional parade routes, and such disputes are typically seen in terms of a zero-sum conflict between two traditions (Mac Ginty \& du Toit, 2007).

Protestant/unionist communities have arguably not fared well in the transition from armed conflict to such cultural competition. Whereas previously they could claim effective ownership of the military and police forces in a violent struggle against 'terrorists', they now find themselves competing culturally against a confident Celtic revival, centred on the Irish language, traditional music, Gaelic sports, and so on. The increasing visibility and status of Irishness is interpreted by some unionists as a wilful removal of Britishness from the province (Hennessey \& Wilson, 1997; Mac Ginty \& du Toit, 2007)

For this reason, we expected Protestants and unionists to report less welcoming attitudes towards immigrant groups in general than Catholics and nationalists. Following the insights of Gilroy (2004) and Clark and Garner (2010), we further predicted that Protestants, who have seen their prior dominant status undermined by the course of events in Northern Ireland, experience a higher level of vulnerability to cultural threat than Catholics do. We expected this higher perception 
of cultural threat among Protestants and unionists to account for the differences in attitudes towards immigrants.

\section{Method}

\section{Datasets}

The study used data from the 2002 and 2009 Northern Ireland Life and Times (NILT) surveys (ARK 2003; 2010). The NILT has been conducted annually since 1998 and is based on random samples drawn from the population of Northern Ireland. We make use of the 2002 and 2009 surveys here. The 2002 survey included sufficient measures to test our hypothesised mediation model. The 2009 survey, meanwhile, allows a supplementary analysis that takes advantage of a much broader range of indicators of anti-immigrant and anti-minority attitudes. Unfortunately, however, the latter survey did not include indicators of cultural threat. For this reason, we report analyses of both datasets in order to take advantage of the particular indicators that were included in each.

Given that our research questions centre on a comparison between Protestant and Catholic populations in Northern Ireland, we included the responses only of individuals who reported belonging to one of these categories. Those indicating another religion or no religion, and those not answering the question, were excluded (a total of 11.6 and 14.4 percent of the population in the 2002 and 2009 surveys respectively). This left sample sizes of 1592 in 2002, and 1051 in 2009.

\section{Measures}


Religious identity. Participants were asked whether they regard themselves as belonging to a particular religion and to specify which. Participants were not prompted with a list of choices, but their responses were subsequently categorized by the survey compliers as Catholic, Protestant or other.

Political identity. Participants indicated whether they think of themselves as a unionist, a nationalist or neither.

Cultural threat. This was measured only in the 2002 dataset, and was indicated by responses to two items: "My cultural tradition is always the underdog" and "I am confident that my own cultural tradition is protected in Northern Ireland these days", answered on a 5-point agreement scale where 1 indicates strong agreement and 5 indicates strong disagreement. Thus, the items do not mention a specific a specific outgroup as the source of threat. Items were recoded such that their mean provides an index of cultural threat with high scores indicating high threat $(\alpha=$ $.69)$.

Anti-immigrant and anti-minority attitudes. In the 2002 survey, negative perception of immigrants was measured using six items. Five of these were measured on a 5-point agreement scale: "Immigrants increase crime rates", "Immigrants are generally good for Northern Ireland's economy", "Immigrants take jobs away from people who were born in Northern Ireland", "Immigrants make Northern Ireland open to new ideas and cultures" and "Refugees who have suffered political repression in their own country should be allowed to stay in Northern Ireland”. A further item asked: "Do you think the number of legal immigrants to Northern Ireland nowadays should be..." and was answered on a 5-point scale anchored at "increased a lot" and "reduced a lot" $(\alpha=.84)$. 
The 2009 survey included a much more extensive set of prejudice items. These included social distance items, in which participants indicated whether they would accept a member of various target outgroups as a resident of Northern Ireland, as a resident in the participant's local area, as a work colleague, as a close friend and as a relative by marriage. These items were dichotomous ( $1=y e s$, accept; $2=$ no, not accept), such that combining the 5 items provided an index of social distance ranging from 1 to 2 for each target group. The target groups were East Europeans $(\alpha=.89)$, other ethnic groups $(\alpha=.89)$ and Muslims $(\alpha=.93)$.

The 2009 survey also asked about the attack on the Romanian families that had taken place that year. Participants indicated their agreement with the following statements about the incident: "It makes me feel ashamed that such attacks are happening", "I don't necessarily agree with the attacks but I sympathise with the reasons behind them", "I totally condemn these kinds of racist attacks" and "I don't have any sympathy for those Romanians". These items were recoded such that a high score indicates a higher level of opposition to the attacks $(\alpha=.76)$. Finally, a similar but slightly expanded set of eight items to the anti-immigrant measure in 2002 was used in 2009 to measure prejudice towards 'migrant workers' $(\alpha=.84)$, again using a 5-point agreement scale.

Demographics. The survey included measures of age, gender and social class (coded by the survey compilers into nine categories based on information provided by the respondents about their employment). We computed eight dummy variables dummy variables from the social class categories. All of these demographic data were used as control variables in the main analyses.

\section{Results}




\section{Mean differences in prejudice indicators}

Table 1 presents the means and standard deviations of all prejudice indicators from the 2002 and 2009 surveys. These demonstrate a consistent pattern whereby the Protestants in the sample report more negative outgroup attitudes across target groups than the Catholics. The t-tests indicate that these differences are all statistically significant.

(Table 1 about here)

\section{Religious and political categories}

Figure 1 shows the proportions of respondents identifying as unionist, nationalist and neither among the Protestant and Catholic samples in 2002 and 2009. These frequencies indicate that while the numbers of Catholic unionists and Protestant nationalists are extremely small, a large proportion- 32.1 and 45.3 percent of the total sample in 2002 and 2009 respectively - indicated neither a unionist nor nationalist political identity. Thus, religious and political categories are not reducible to one another. In the analyses that follow, we therefore examine independent effects of religious and political category membership on the prejudice indicators.

(Figure 1 about here)

\section{Identity and anti-immigration attitudes}

We now examine whether participants who categorized themselves as Protestants or Unionist held significantly stronger anti-immigration attitudes than participants who chose to categorize themselves as Catholic or Nationalist, across 
diverse target outgroups. To this end we used the data from the 2009 wave of the NILT, which provides measures of social distance towards Eastern Europeans, Muslims and other ethnic groups, as well as attitudes about migrant workers and about the 2009 attacks on Romanian families in Belfast. Missing values on the prejudice and threat indicators (less than 5 percent of cases for any one indicator) were imputed using regression imputation, with all other indicators serving as predictors.

To assess the relationship between participants' religious and political identification, and their attitudes towards these groups, we carried out five separate path analyses using latent factors for the five outcome variables. The predictors were all dichotomous (i.e., Protestant vs. Catholic, Unionist vs. Neither, and Nationalist vs. Neither) and their co-variances were freely estimated. To determine the "goodness-offit" of these models, we used several indicators in addition to the chi-square test, which is known to be very sensitive to large sample sizes, such as the Comparative Fit Index (CFI) and the Root Mean Square Error of Approximation (RMSEA). Values more than .90 for the CFI and less than .05 for RMSEA are considered to be indicators of an adequate model fit (Byrne, 2006). All analyses were carried out using MPlus version 4.2 (Muthen \& Muthen, 2006).

(Figure 2 about here)

As Figure 2 shows, compared to those participants who identified themselves as Catholic, Protestant participants held significantly stronger prejudicial attitudes towards Muslims, Romanian families and migrant workers. There was no difference between the two groups with respect to their attitudes towards Eastern Europeans and 
other ethnic groups. In terms of participants' political identities, those participants who identified as unionists were significantly more likely to endorse prejudice towards each of the target group except 'other ethnic groups', compared to the baseline group who reported neither unionist nor nationalist identity. Participants who identified as nationalist were significantly more prejudicial than the baseline group only in relation to Muslims and migrant workers. Therefore, although identification as a nationalist in Northern Ireland is not unrelated to anti-immigrant prejudice, there is more consistent evidence for negative effects of a unionist political identity on attitudes towards different ethnic and religious groups. As Table 2 indicates, all five models showed good fit.

(Table 2 about here)

\section{The mediating role of cultural threat}

Having established the differences between Protestants and Catholics, and between unionists and nationalists, in attitudes towards immigrants and minorities, we set out to investigate the mediating role of perceived cultural threat using data from the 2002 wave of the NILT. Table 3 displays the correlation coefficients amongst the different identity measures, cultural threat and anti-immigration attitude. As can be seen from this table, the strongest relationship is observed between holding an antiimmigration attitude and cultural threat $(r=.35)$. Thus, higher levels of perceived cultural threat are significantly associated with a much stronger negative attitude against immigration to Northern Ireland. Furthermore, Protestant participants showed significantly stronger negative attitudes towards immigration compared to Catholics, as did those participants who thought of themselves as unionist. In contrast, 
participants who reported a nationalist political identity were significantly less prejudiced against immigration. Finally, both Protestant and unionist participants were significantly more likely to perceive their cultural heritage to be under threat compared to Catholic and Nationalist participants.

(Table 3 about here)

To test the mediating effect of cultural threat on the relationship between religious and political identity, and anti-immigration attitudes, we estimated a structural equation model using latent factors for cultural threat and anti-immigration attitude, as shown in Figure 3. Again, the co-variances amongst our predictor variables were freely estimated. The same imputation procedure used for the 2009 dataset was again used here. This time the proportion of imputed values for each variable ranged from 5.5 percent to 14.5 percent. $^{1}$

(Figure 3 about here)

The results clearly indicate that perceived cultural threat fully mediates the effect of religious identity, but only partially the effect of one's Unionist political identity on anti-immigration attitudes. Thus, participants who identify with either the Protestant or Unionist community are more likely to perceive their cultural heritage to be under threat which is then further associated with a negative attitude towards immigrants in Northern Ireland. To determine the significance of the mediating effects of cultural threat, we used the bootstrap procedure as outlined by Shrout and

\footnotetext{
${ }^{1}$ Conducting the same analysis with pairwise deletion rather than imputed values yielded virtually identical parameters and fit indices.
} 
Bolger (2002). Based on 1,000 bootstraps, the means of the unstandardized indirect effects of participants' religious identity and unionist political identity on their attitudes towards immigration are .11 with a $95 \%$ CI $(.047, .181)$ and .14 with a $95 \%$ CI (.057, .226), respectively. Given that neither confidence interval contains the value of zero, we can conclude that perceived cultural threat significantly mediates the relationship between religious and unionist political identities, and anti-immigration attitude. There was no evidence for a mediating effect of cultural threat on the relationship between one's Nationalist political identity and their beliefs on immigration.

\section{Discussion}

Our analyses indicate that across a range of target outgroups, Protestants report higher levels of prejudice than Catholics, and that unionists report more prejudice than people reporting no political identity. The difference in prejudice levels between nationalists and people reporting neither political identity is less pronounced, only reaching significance in the case of migrant workers and Muslims. It is important to note that these differences emerge over a number of target groups, and not only those who might be categorized as a religious outgroup by Protestants but not by Catholics. As van Rijskwijk et al. (2009) have demonstrated, Northern Irish Protestants' reactions to Polish migrants can be affected by whether the predominant religion of Poland (Catholicism) is made salient, thus rendering Poles a religious outgroup that is seen as potentially more threatening. We concur with van Rijswijk et al. on the importance of particular forms of categorization in determining reactions to migration. However, our analysis suggests that the difference between Catholics' and Protestants' attitudes towards immigrants cannot be interpreted simply in terms of the 
immigrant groups sharing a religious category with Catholics but not with Protestants. Indeed, if one considers the three social distance measures, the difference between Protestants and Catholics is greatest (and the effect size strongest) in the case of Muslims, who obviously do not share a religious category with either Protestants or Catholics.

We found that the higher levels of prejudice among Protestants and unionists is mediated by cultural threat: that is, these respondents see their cultural traditions as being the 'underdog' and as not being protected, and this perception in turn predicts more negative attitudes towards migrant workers. Being a unionist is associated with higher cultural threat over and above the differences between religious groups. Thus, cultural threat mediates both religious and political differences in attitudes towards immigrants.

It must be emphasised that anti-immigrant and anti-minority prejudice are far from absent among the Catholics and nationalists in the sample. Mean levels of antiimmigrant attitudes among Catholics are well within one standard deviation of the scale midpoint, with substantial numbers were in active agreement with the items expressing prejudice. Furthermore, as we have said, nationalists in the 2009 do report more prejudice towards Muslims and migrant workers than do people claiming neither political identity. Similarly, we must also emphasise that both Protestants and Catholics tended to oppose the 2009 racist attacks on Romanian families in Belfast. It was certainly not the case that Protestants generally supported these attacks, even if the opposition was strongest among Catholics. It should also be noted that part of the difference in reaction to these attacks may be explained by the fact that they took place in a predominantly protestant part of the city, and the perpetrators are therefore 
assumed to have been Protestants. Had this not been the case, it is possible that the reactions of Protestants and Catholics would have been different.

As a secondary analysis, our contribution is necessarily constrained by the items included within the survey that we used. This gives rise to a number of limitations. For example, the absence of cultural threat indicators in the 2009 meant that we were unable to test its meditating role across the range of prejudicial attitudes measured in that survey. It is also unfortunate that the surveys did not allow for the strength of religious and political identities to be included in the model, as an alternative to the potentially simplistic categorisation of the sample into Protestants and Catholics. On the other hand, the indicators of threat used in the NILT survey have the notable advantage of not referring to specific outgroup as a source of threat. There is therefore not the danger of tautology associated with typical intergroup threat measures (Sniderman et al., 2004; Sniderman \& Hagendoorn, 2007). We can infer instead that the perceived weakness and vulnerability to cultural threat is indeed meaningfully related to negative outgroup attitudes, rather than threat measures merely tapping a general antipathy towards those groups. This is crucial given our contention that Protestants and unionists experience their cultural traditions to be under threat as a consequence of measures to bring about 'parity of esteem' by undoing the privileged status of Britishness, as opposed to Irishness, within Northern Ireland.

We therefore argue that cultural threat remains an important focus of research, especially on immigration, but that the origins of such threat in political processes need to be elaborated. It is insufficient to regard it merely as a direct reaction to cultural difference, since this would not explain why different groups within Northern Ireland experience it differently. Rather, our results suggest that cultural threat 
follows from a challenged position of primacy, previously enjoyed by unionists by virtue of their effective ownership of the state, but now weakened by the recognition of the legitimacy of Irish nationalism. While the context that we have examined here differs in important ways from others in which cultural threat is of interest, such as Great Britain and the Netherlands, it is this more politicised characterisation of cultural threat that we see as fertile ground for future work.

\section{References}

ARK. (2003). Northern Ireland Life and Times Survey, 2002 [computer file]. ARK www.ark.ac.uk/nilt [distributor].

ARK. (2010). Northern Ireland Life and Times Survey, 2009 [computer file]. ARK www.ark.ac.uk/nilt [distributor].

Cassidy, C., \& Trew, K. (2004). Identity change in Northern Ireland: A longitudinal study of students' transition to university. Journal of Social Issues, 60, 523-540.

Clark, S., \& Garner, S. (2010). White Identities: A Critical Sociological Approach. London: Pluto.

Farrell, M. (1976). Northern Ireland: The Orange State. Pluto Press, London.

Gilroy, P. (2004). After empire: melancholia or convivial culture? London: Routledge.

Hennessey, T., \& Wilson, R. (1997). With all due respect Pluralism and parity of esteem. Belfast: Democratic Dialogue.

Hewstone, M., Cairns, E., Voci, A., Hamberger, J., \& Niens, U. (2006). Intergroup contact, forgiveness, and experience of "The Troubles" in Northern Ireland. Journal of Social Issues, 62, 99-120. 
Jarman, N. (2008). Hate crime in Northern Ireland: An overview. Belfast: Institute for Conflict Research.

Livingstone, A., \& Haslam, S. A. (2008). The importance of social identity content in a setting of chronic social conflict: Understanding intergroup relations in Northern Ireland. British Journal of Social Psychology, 47, 1-21.

Mac Ginty, R., \& du Toit, P. (2007). A disparity of esteem: Relative group status in Northern Ireland after the Belfast Agreement. Political Psychology, 28, 13-31.

McAuley, J. W., \& Tonge, J. (2007). " For God and for the Crown": Contemporary political and social attitudes among Orange Order members in Northern Ireland. Political Psychology, 28, 33-52.

McLaren, L. (2003). Anti-immigrant prejudice in Europe: Contact, threat perception, and preferences for the exclusion of migrants. Social Forces, 81, 909-936.

McLaren, L., \& Johnson, M. (2007). Resources, group conflict and symbols: Explaining anti-immigrant hostility in Britain. Political Studies, 55, 709-732.

Muldoon, O. T., Trew, K., Todd, J., Rougier, N., \& McLaughlin, K. (2007). Religious and national identity after the Belfast Good Friday Agreement. Political Psychology, 28, 89-103.

Muthen, LK \& Muthen, B.O. (2006). Mplus user's guide (4th ed.). Los Angeles: Muthen \& Muthen.

Northern Ireland Affairs Committee (2005). The challenge of diversity: Hate crime in Northern Ireland. London: The Stationary Office Limited.

Shirlow, P., \& Murtagh, B. (2006). Belfast: Segregation, violence and the city. Pluto Press. 
Sides, J. \& Citrin, J. (2007). European opinion about immigration: The role of identities, interests and information. British Journal of Political Science, 37, 477-504.

Sniderman, P. M., \& Hagendoorn, L. (2007). When Ways of Life Collide : Multiculturalism and its Discontents in the Netherlands. Princeton: Princeton University Press.

Sniderman, P. M., Hagendoorn, L., \& Prior, M. (2004). Predisposing factors and situational triggers: Exclusionary reactions to immigrant minorities. American Political Science Review, 98, 35-49.

Southern, N. (2007). Protestant Alienation in Northern Ireland: A Political, Cultural and Geographical Examination. Journal of Ethnic and Migration Studies, 33, 159-180.

Tam, T., Hewstone, M., Kenworthy, J., \& Cairns, E. (2009). Intergroup trust in Northern Ireland. Personality and Social Psychology Bulletin, 35, 45.

van Rijswijk, W., Hopkins, N. \& Johnston, H. (2009). The role of social categorization and identity threat in the perception of migrants. Journal of Community and Applied Social Psychology, 19, 515-520.

Weldon, S. A. (2006). The institutional context of tolerance for ethnic minorities: A comparative, multilevel analysis of Western Europe. American Journal of Political Science, 50, 331-349. 
Table 1

\begin{tabular}{|c|c|c|c|}
\hline & \multicolumn{2}{|c|}{ Mean (s.d.) } & \multirow[t]{2}{*}{$t$} \\
\hline & Protestants $^{\mathrm{a}}$ & Catholics $^{\mathrm{b}}$ & \\
\hline \multicolumn{4}{|l|}{2002 SURVEY } \\
\hline Cultural threat & $3.09(.97)$ & $2.48(.79)$ & 13.51 \\
\hline $\begin{array}{l}\text { Anti-immigrant } \\
\text { attitude }\end{array}$ & $3.17(.83)$ & $2.76(.81)$ & 11.14 \\
\hline \multicolumn{4}{|l|}{2009 SURVEY } \\
\hline \multicolumn{4}{|l|}{ Social distance } \\
\hline Eastern Europeans & $1.22(.35)$ & $1.11(.25)$ & 5.77 \\
\hline $\begin{array}{l}\text { Other ethnic } \\
\text { groups }\end{array}$ & $1.17(.31)$ & $1.10(.25)$ & 3.69 \\
\hline Muslims & $1.43(.42)$ & $1.24(.37)$ & 7.81 \\
\hline $\begin{array}{l}\text { Anti-migrant worker } \\
\text { attitude }\end{array}$ & $3.07(.65)$ & $2.71(.70)$ & 8.53 \\
\hline $\begin{array}{l}\text { Opposition to attacks } \\
\text { on Romanian families }\end{array}$ & $3.71(.73)$ & $4.15(.63)$ & -10.36 \\
\hline
\end{tabular}

Note: ${ }^{\mathrm{a}} \mathrm{N}=891 / 547$ in $2002 / 2009 ;{ }^{\mathrm{b}} \mathrm{N}=701 / 504$ in 2002/2009. Based on the

complete dataset including the imputed values for prejudice and threat indicators. All $\mathrm{t}$ statistics are significant at $\mathrm{p}<.001$. Positive values of $t$ indicate higher scores among Protestants compared to Catholics. Equal variances are not assumed. 
Table 2 Measures of fit for the five models predicting attitudes towards different minority groups

\begin{tabular}{lccccc}
\hline \multicolumn{1}{c}{ Target group } & $\chi^{2}$ & df & CFI & RMSEA & 90\% C.I. \\
\hline Eastern European & 123.03 & 55 & .978 & .035 & $.027-.043$ \\
Other ethnic groups & 130.20 & 56 & .978 & .036 & $.028-.044$ \\
Muslims & 250.05 & 57 & .956 & .058 & $.050-.065$ \\
Romanian Families (2009) & 65.04 & 40 & .980 & .025 & $.013-.035$ \\
Migrant workers & 255.06 & 108 & .948 & .037 & $.031-.042$ \\
\hline
\end{tabular}


Table 3 Zero-order order correlation coefficients (NILT 2002)

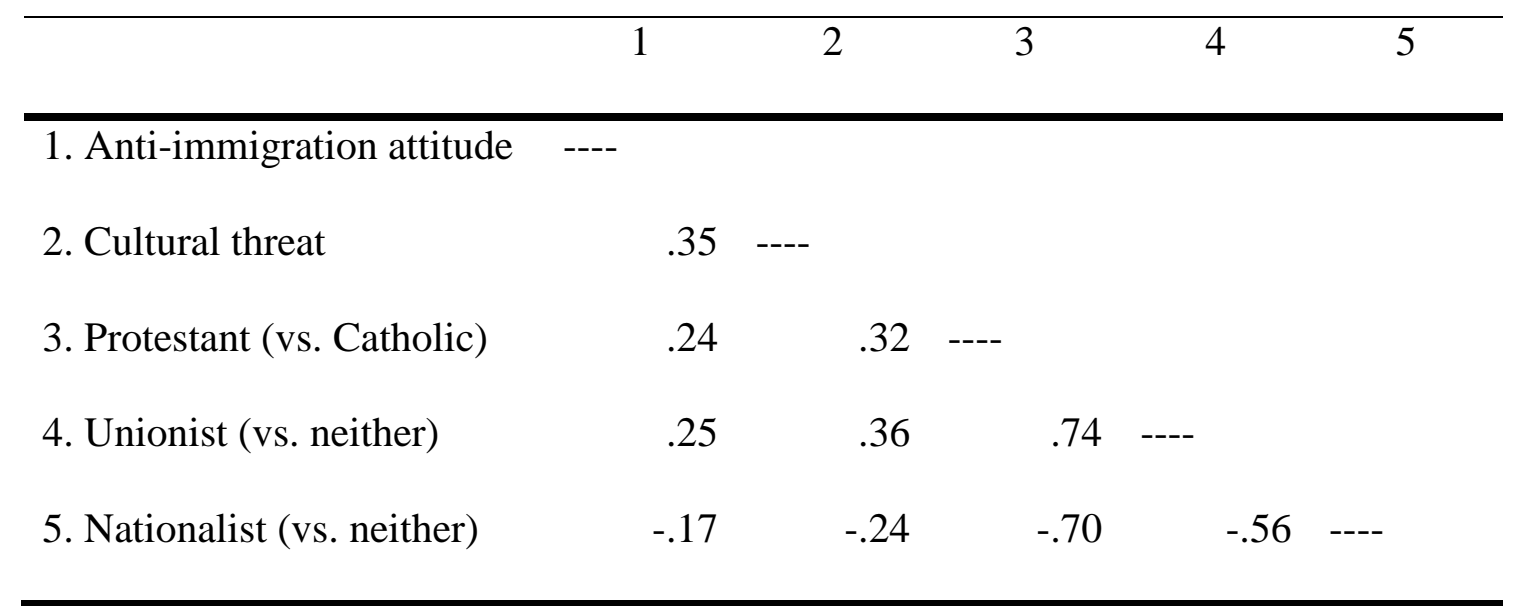

Notes: $N($ listwise $)=1564$; all correlation coefficients are significant at $p<.001$ 
Figure 1

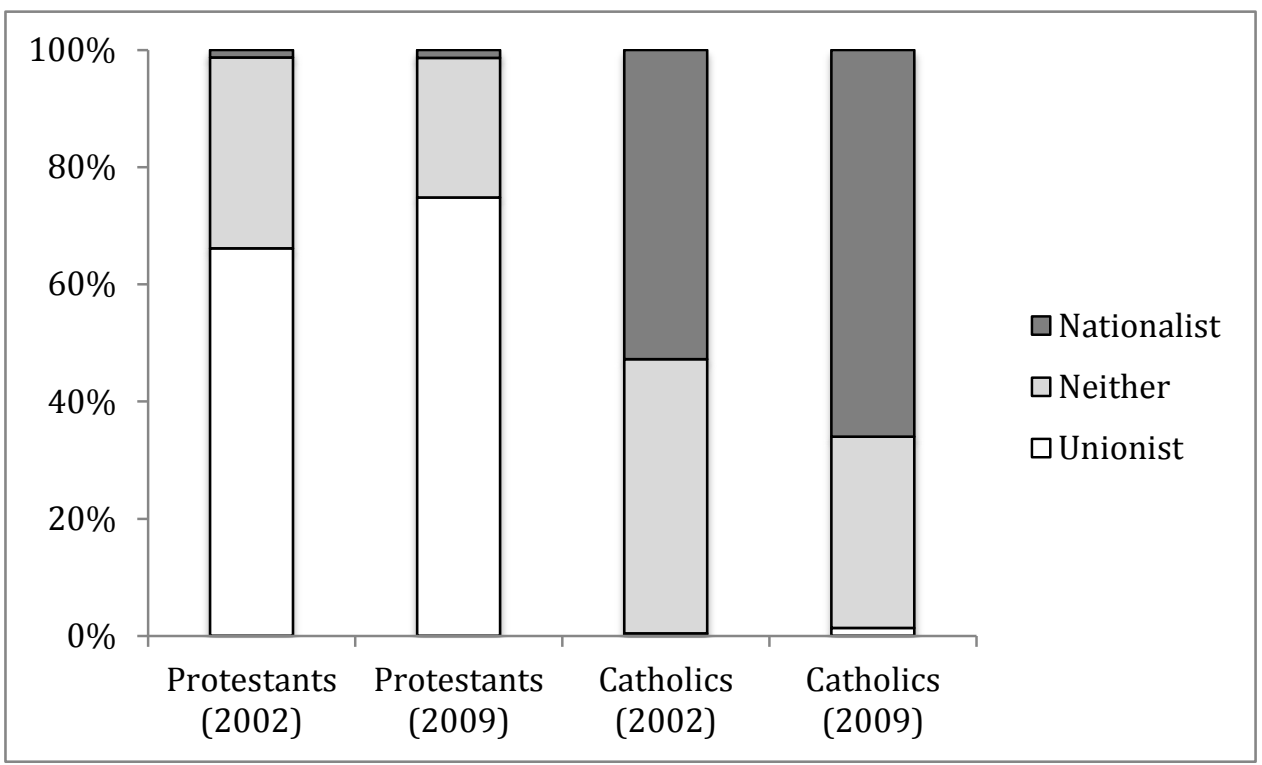


Figure 2 Religious and political categorization/identification effects on prejudice towards different minority groups (2009 sample)

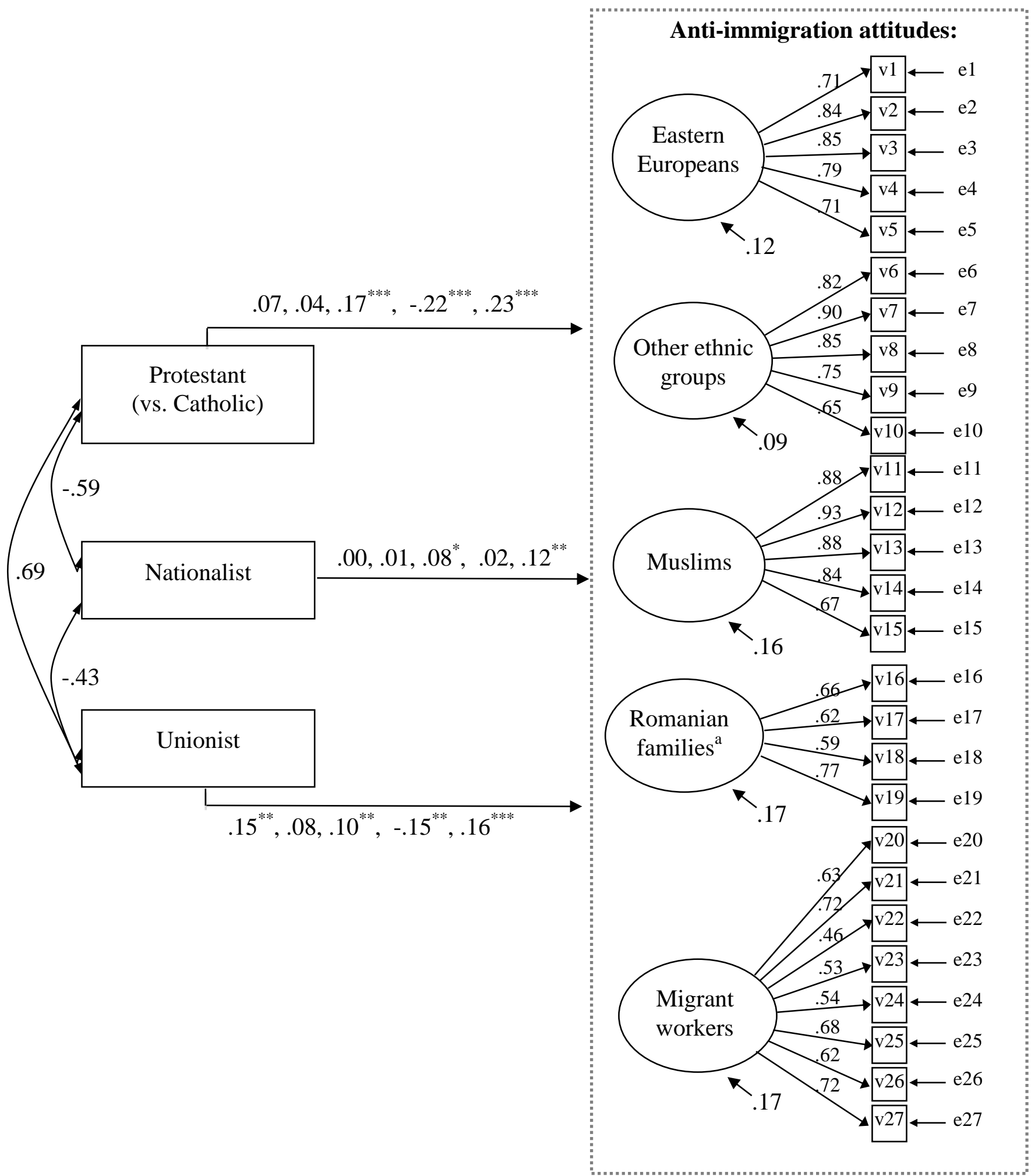

Notes: ${ }^{*} p<.05,{ }^{* *} p<.01,{ }^{* * *} p<.001 ; \mathrm{N}=1020 ;{ }^{\text {a }}$ Items worded positively indicating a positive attitude towards the Romanian families involved in the 2009 racist attacks; The path coefficients represent standardized beta values. The beta values for the paths from religious and political identification to the five outcome variables are listed in the same order in which the target groups of anti-immigration attitudes appear on the right-hand side of the diagram; The observed effects are controlled for age, gender and socio-economic status. Reduction in sample size from that present in the descriptive statistics is due to 31 cases having incomplete socio-demographic data. 
Figure 3 Mediation analysis (NILT 2002)

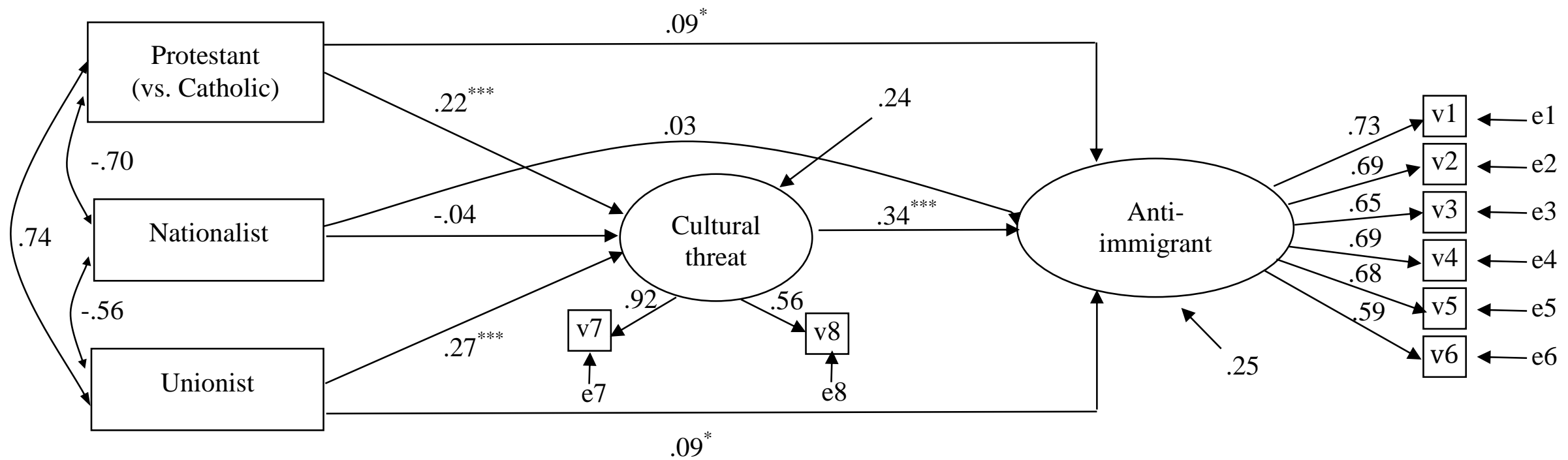

Notes: ${ }^{*} p<.05,{ }^{* *} p<.01,{ }^{* * *} p<.001 ; \mathrm{N}=1541 ; \chi^{2}(79)=302.60, p<.001, \mathrm{CFI}=.95, \mathrm{RMSEA}=.043$ (90\%CI: .038 - .048). The observed effects are controlled for age, gender and socio-economic status. Reduction in sample size from that present in the descriptive statistics is due to 51 cases having incomplete socio-demographic data. 